\title{
Will Businesses and Business Schools Meet the Grand Challenges of the Era?
}

\author{
Sandra Waddock \\ Carroll School of Management, Boston College, Chestnut Hill, MA 02467, USA; waddock@bc.edu
}

Received: 29 June 2020; Accepted: 23 July 2020; Published: 29 July 2020

check for
updates

\begin{abstract}
Meeting today's grand challenges means changing the economics paradigm that informs both business practice and business/management education. This paper asks whether business schools meet the challenges of the 21st century and argues not without shifting away from the core-neoliberal-paradigm of economics. This essay makes the following argument. Paradigms shape narratives. Changing core narratives is a powerful lever for transformation. Narratives are constructed of core ideas (memes) that replicate readily from mind to mind. Neoliberalism's memes are pervasive and highly resonant in business schools. To move towards sustainability, the fundamentals taught in business school need to shift away from neoliberalism's tenets towards what gives life to economic systems. From a theory perspective, neoliberalism's lack of attention to social and ecological consequences of economic activity plays a large part in shaping today's crises, including the pandemic, climate change, and biodiversity loss. A new/next economics paradigm is needed that shifts away from an emphasis on only financial wealth and constant economic growth on a finite plant towards life-centered economies that foster wellbeing and flourishing for all, creating what scholars call collective value. The result of this analysis is a conceptualization supporting new memes that include collaboration and competition, stewardship of the whole system, a cosmopolitan to local sensibility, and recognition of humanity's deep embeddedness and connection with other people, other beings, and nature. The article concludes that business schools need to meet this challenge head on, changing the fundamentals of what is taught and why.
\end{abstract}

Keywords: sustainability; business schools; management education; transformation; system change; neoliberalism; memes

\section{Introduction}

The world's human population is struggling with a number of potentially civilization-threatening socio-ecological crises: climate change, sustainability, and potential ecosystem collapses, growing inequality [1] and attendant social unrest, and the sixth great species extinction [2,3]). The world is facing topsoil erosion, problematic industrial agricultural and animal husbandry practices, structural racism, as well as poverty $[4,5]$. These issues, and the list could go on, suggest that the world is facing problems in numerous domains of significant proportions, all of which could potentially benefit from what is sometimes called responsible management and leadership [6,7].

The question at the core of this Special Issue arises: can and will businesses and business schools meet these and other grand challenges? The short answer: not without a major paradigm shift, a transformation. That said, businesses (and even b-schools) have the innovation capacity to make significant changes when pressed, as the quick response to the Covid-19 pandemic has aptly demonstrated. Meeting grand challenges, however, requires new mindsets, paradigms, and ways of thinking and acting. In part, that is because some of today's dominant economic and management theories have created significant disparities and ecological issues, and in part because, as Einstein 
famously said, "We can't solve problems by using the same kind of thinking we used when we created them."

\section{Theoretical Framework}

System transformation is a matter of vision/imagination, will, and motivation-and sometimes crisis, as in the case of the pandemic, which greatly "unfroze" thinking in the sense that Lewin meant when discussing the change processes of unfreezing, change, and refreezing [8]. Arguably, until the narrative or "stories" that we tell ourselves as business people and scholars about what we are doing, why we do it, and for whom begin to shift in dramatic ways, neither businesses nor the b-schools that support them will sufficiently transform to meet today's grand challenges. The problem is that too many businesses and b-schools are stuck in an old, misguided, and dysfunctional story that shapes mindsets and guides actions. Despite pressures to reestablish legitimacy and meet the challenges of sustainability and inequality the power of today's metanarrative remains entrenched [1,9-11]. For these institutions to truly meet today's grand challenges requires significant transformation of the stories that shape the paradigms or perspectives that guide their purposes, performance metrics, power relations, and practices [12]. At the moment, however, it does not look much like any sort of real transformation is taking place in either businesses or b-schools. Indeed, the major discussion is around how to cope with the manifold crises facing the world and how to bring back what amounts to business as usual to the extent possible (see also [1]). Yet it is business as usual that is largely responsible for these crises.

There has, in recent years, been (mostly unrealized) talk of transforming business to deal with climate change in particular [13]. Of course, b-schools have been under serious critique for years, to little avail (e.g., [14-19]). Until the Covid-19 pandemic struck, however, actual transformation efforts were largely superficial. Most changes in both businesses and b-schools focus on doing more and better at what is already being done. Further, many critiques have been raised about the impact of today's economics, economic thinking on students [20]. They claim what is needed is a new or next economics that puts life or wellbeing itself, rather than wealth maximization, as the central goal [11,21-23]. So far, few businesses or b-schools are as yet making the necessary transformation that could stop the destructive impacts of today's dominant narrative of neoliberalism [24].

Before the pandemic, "transforming business" mainly emphasized doing more and better at what was already being done or adopting new technologies that could make businesses more efficient [12]. Mostly, such changes just focus on doing more of and being better at what is already being done. Thus, though there has been some talk of transforming business, to date it has been largely superficial. Sometimes, such change simply means adopting new technologies that could make businesses more efficient at what they are already doing [12]. Those kinds of shifts are incremental rather than transformative [25].

At this writing, it does not look much like any sort of real transformation is taking place in either businesses or b-schools-not even incorporating more of the liberal arts or what Currie, Davies and Ferlie call "lowering their walls" [26]. Indeed, the major thrust that can be heard is how to bring back what amounts to business as usual. A piece about how companies can recover from the impacts of the pandemic from the global consulting firm McKinsey is both typical and instructive [27]. McKinsey argues that rebuilding needs to take place in four strategic areas: "recovering revenues, rebuilding operations, rethinking the organization, and accelerating the adoption of digital solutions". According to McKinsey, companies need to rapidly focus on rebuilding revenues, become considerably more agile so they can quickly reinvent their global value chains, work in new ways to ensure continued growth, and adopt new technologies that better meet new customer expectations. The only mention of sustainability in this piece is to ensure continued company viability. It is the same old thing in recovery mode.

Yes, post-pandemic and during recovery, some things like customer and employee expectations may change. Much more may be done online than in the past, including customer ordering and employees working remotely. Supervision and management practices will have shifted-as employees 
gained independence and took responsibility for their work, with assessments having to be on the basis of the quality of the work, rather than "face time". Basically, as with many policy makers and business leaders, the thinking is to bring back business as usual to the extent feasible. No real changes to the business model are envisioned.

Much the same can be said of b-schools, as longtime b-school observer John Byrne observed in Poets $\mathcal{E}$ Quants. Sure, some of the impacts of the move to remote and online teaching forced by the pandemic will linger. As Byrne notes, more classes will "flip", and other activities will be held virtually [28]. But real transformation? Even discussion of curriculum content? Not so much. Byrne argues that even structural changes that might be considered (shorter programs, online executive education) are likely to be limited, though some pedagogical innovation is likely as a result of student demand.

At my own institution, multiple structures for classes were in play for the fall 2020 semester-in person (if feasible), synchronous remote, asynchronous online, and various hybrids that have some students present some of the time and remote at other times, or various combinations of the former. No matter the format, faculty have learned that guest speakers can now "zoom in" and be effective with classes remotely if desired, from virtually anywhere. Further, both faculty and students will be used to such online conversations. Case discussions and group work can take place in a variety of formats, e.g., through shared documents, group meetings held online, and threaded conversations, among others. Students and faculty alike can post videos addressing different questions, doing case analyses, or presenting group and individual projects and perspective.

So, yes, some things will change in both businesses and b-schools in the wake of the pandemic. But ...

\section{Methodological Approach: Shifting Content and the Need for New Stories}

The "hows" of business practice and b-schools delivery of education are necessarily undergoing considerable change to cope with the impacts of the pandemic. What is less likely to change in b-schools or in the practice of business or at least not much-and what needs most to change-is the "what". The "what" is the content of management education. This "what" is based on a dominant story-the story or narrative of business. Today's dominant story, neoliberal economics, is both flawed and highly problematic $[10,22,23,29]$.

Since human beings are fundamentally story-telling creatures, the stories that we tell matter [30]. When they are foundational, they are what anthropologists call cultural mythologies (myths) and they inform just about everything we do [31]. Stories that are particularly dominant are sometimes called metanarratives and the tenets of neoliberalism have become such a metanarrative today $[10,32]$. Living in the context of such a metanarrative can be like breathing air-it is so familiar that we sometimes do not even realize that we are living in it. Until the pandemic made it quite obvious, much of the Western "developed" world was living in the metanarrative of neoliberalism, a story about how our economies-actually, the broader idea of societies—ought to work.

Systems thinker Donella Meadows argued that the most important key to system transformation is changing the paradigm or mindset, along with the ability to transcend the current mindsets that people hold [33]. Mindsets and paradigms are, essentially, the stories we are telling ourselves about how the world works. The narratives and stories that we tell today about what businesses are for and how they do and ought to operate today are based in an extreme form of neoliberalism that has taken over economic thinking since the so-called Reagan-Thatcher revolution of the early 1980s. Powerful stories and narratives like today's "metanarrative" of economics (and also scientific reasoning, which in many ways modern economics tries to emulate) are based on what biologist Richard Dawkins called "memes". Memes are core units that are the building blocks of culture (similar to genes as biological building blocks) [34]. As elaborated by Susan Blackmore, memes can be words, phrases, ideas, symbols, images, or even brands [35]. Essentially, as Blackmore details, they are ideas that replicate from one human mind to others when they are resonant-and therefore successful. People construct narratives, stories, and paradigms out of these building blocks—memes [36]. 
Stories and narratives, constructed out of memes, when powerful and resonant, shape mindsets and create paradigms. The foundational story that informs business/b-school thinking today is based on neoliberal economics It is a fairly extreme form of neoliberalism at that) [32,37]. The pandemic has made clear some of the fractures created by this story. The stories that we tell ourselves about what businesses are "for" (as Charles Handy once noted) [38]. That is, business purposes guide strategies, managerial practices, and how work is done. Additionally, and importantly, performance metrics matter, because as any accountant would likely say, "you get what you measure (and reward)". Paradigms or stories and the mindsets, paradigms, and perspectives they shape, along with performance metrics, are important drivers of strategies and operating practices, as well as power distribution in companies and other institutions [39].

\section{Background: The Old Story—Neoliberalism}

Just what is the neoliberal "story" that pervades both b-schools and business practice? For one thing, economist Milton Friedman, one of the most well-known proponents of neoliberal thinking, famously argued in a 1970 New York Times article that the (only) "social responsibility of business is to increase its profits" [40]. Core memes associated with neoliberalism include the erroneous idea, drawn from Adam Smith, that humans are always self-interested profit maximizers [41]. Neoliberalism also asserts that markets are the way to solve most problems, including social problems, and that such markets ought to be free along with trade among nations [32].

Further, neoliberalism emphasizes continual economic and financial wealth growth, both of whole "economies" and of companies. It also argues that all responsibility is individual rather than collective and that, in essence, society does not exist. Neoliberalism argues that the less government there is, the better, markets will solve social problems, and free markets and trade are always good things, no matter their societal or national implications. This belief system, which can be deeply held by its proponents, ignores ecological impacts of economic activity and argues for continual growth of financial wealth, which is the only value that seems to matter. Such beliefs are now deeply embedded in the popular imagination as core aspects of a widely shared set of beliefs, a core cultural myth, about the nature of the economy. Importantly, in the current context, neoliberalism ignores the effects of economic impacts on society and the natural environment, labeling them externalities. What that really means is that someone other than the perpetrator will be paying for them because they are distributed—often the whole of society, either in what John Ruskin called greater "illth" (the opposite of wealth in its original meaning of wellbeing) or through public means (taxes). Externalities, when negative, are "public bads", like pollution and global warming that hurt all, or public goods like parks and sidewalks that everyone can benefit from.

Neoliberal ideas profoundly shape what is taught in businesses schools and ultimately how business leaders and managers who have come through b-schools shape their businesses. The assumptions of neoliberalism make up the implicit and sometimes explicit managerial mindset, e.g., in the idea of continual growth in revenues, economies, markets, and company size. They pervade the b-school curriculum in assumptions about what really matters-profitability and financial wealth above all else, continual growth in markets, company size, number of employees, and other attributes, including stock price, with embedded ignorance of community/social impacts and effects on the natural environment.

Such assumptions have devastating socio-ecological and ethical consequences, permitting slogans like "it's just business" to explain inhumane or cruel practices. They underpin "efficiency" arguments including often unquestioned down- and right-sizing of companies, abusive working conditions in many global supply chains, cruel and inhumane animal husbandry practices, employee layoffs to save share prices, and many other destructive practices. These things are done in the interests of efficiency without consideration of issues of responsibility, ethics, or sustainability, because, after all, business is supposed to be focused on making profits-and no other value matters. 
Worse, most of neoliberalism's assumptions are simply wrong. In effect, they are telling a misleading story - and it is a misleading story with enormous consequences for the wellbeing of employees, customers, communities, and ecosystems, while benefitting mainly one stakeholder group-investors. For example, much evidence from biology tells us that neither humans nor some animals are always self-interested. In many biological contexts, caring behaviors and symbiosis (collaboration) are as or more important for survival than competition, including in human societies [42-45].

Too, today's markets hardly resemble the many suppliers, many customers description offered by Adam Smith on which neoclassical economics is supposedly built. Despite that scholar Gerald Davis argues that there is a shrinking overall population of large corporations [46], today's "markets" are mostly taken to mean stock exchanges, the focus of much economics thinking in the popular press. These stock exchange markets are populated by large corporations that are frequently oligopolies and sometimes monopolies. Even in business practice, there is hardly anything resembling the free competition that Smith expected. Local small- and medium-sized businesses (SMEs) of which there are millions in the world, and which supply most of the jobs, are ill-considered in the neoliberal context—or, for that matter, in most b-schools.

As to solving social problems, it has long been recognized that there are many public issues-public goods like clean water, clean air, societal wellbeing, universal healthcare, and the like-that "free" markets cannot or will not supply. Further, societies do exist with very different norms and cultures. We humans are not only storytelling creatures but also communal beings, which the isolation imposed by the Covid-19 pandemic has highlighted in glaring color. As the pan-African notion of Ubuntu states, "I am because we are". Humans do not survive, never mind thrive, in the absence of community-society. As to the laissez-faire governments that neoliberalism demands, the Covid-19 crisis has, if nothing else, put the lie to that one: when so many billions of people around the world are now reliant on good government to deal effectively with the impacts of the disease-and the negative results apparent when governments do not work effectively.

The "efficiency" argument is one that relies on an "anything goes" in the interests of the profits mindset. Neoliberalism fosters an amoral approach to business that seems to mean that whatever needs to be done in the name of profitability and growth is all right. But businesses and economics, which were originally about household management (not whole societies), are fundamentally moral activities because they affect both people and planet - the essence of what ethics is about [29].

The constant growth argument is particularly pernicious. For one thing, it is unrealistic to expect any population (like humans) or economic activity to grow endlessly on a finite planet [44]. For another, it effectively confuses growth in financial wealth with wellbeing and flourishing [22]. Of course, the major metrics/indicators that are used-and taught extensively in b-schools and referenced constantly in the business press-are that of GDP for economics, a measure known to be flawed since its inception, which measures only economic activity whether that activity is beneficial or means doing something like destroying ecosystems [47]. For businesses is it profitability or, worse, shareholder wealth, all measured solely in financial terms, with little regard for the original meaning of wealth, which is associated with wellbeing.

It is time, as numerous observers cited above have stated, for a new story $[11,29,32]$.

\section{Implications for B-School Practice and Future Research: A Life-Centered Economics}

What are the implications for b-schools, scholars, and future research? Are there alternatives to neoliberalism? Might it be time to give up the dream of efficiency in the interests of what used to be known as the common good? In the wake of the Global Financial Crisis of 2007-08, dozens if not hundreds of initiatives emerged around the globe arguing for a new economics and what are sometimes called next economies. Many such initiatives are now allies of the transformation catalyst (as I and Steve Waddell have labeled such entities in a working paper.), WEAll, the Wellbeing Economy 
Alliance, which is attempting to bring them into alignment in the interest of creating a powerful new narrative to counter the current one, called in WEAll's lingo, a wellbeing economy.

A new narrative needs to be as emotionally and intellectually resonant, inspiring, and compelling as the current one is [35]. If resonant, it would (eventually) bring about a very different mindset (paradigm) oriented towards different business purposes, metrics, and practices, shifting what is taught in b-schools rather dramatically, and also shifting business practice. At this writing, there are global, regional, and local initiatives attempting to bring such next economies with a new economics at their core into existence-despite the resistance and likely obstruction of existing institutions, especially global financial institutions, and despite embedded thinking in textbooks, which now dominate economic thinking—and permeate b-schools.

Scanning the websites of WEAll's initial next economies allies suggests a number of shared or common themes (memes) that provide a potential basis of thinking about new economics and next economies-subjects rife for future research. Terms like life-centered, flourishing, regenerative, wellbeing, and valuing all of humanity and life are at the core of next economies thinking. Such memes emphasize an orientation towards the wellbeing or flourishing of all, including non-human beings and even whole ecosystems. They call to mind the seminal work by Donaldson and Walsh on business purpose, which argues that the core purpose of business is to create what they termed collective value absent dignity violations [48].

This perspective on business purpose effectively argues for both a stakeholder and ecological mindset or what some call a sustainability mindset, another area needing further study [49]. This new mindset or paradigm encompasses not the narrow purpose of shareholder wealth maximization embedded in today's business logic but a sense of what has elsewhere been called stewardship of the whole [50]. Such a transformation of business purpose would bring businesses, particularly corporations, back to their original construction-as social institutions serving the public good or public interest, rather than simply investors' interests [51]. It would also mean a relatively massive, but much needed reorientation of the purposes of businesses, and, concomitantly, of b-schools, answering some of the many critiques that have been raised about b-schools and business scholarship in the past $[1,15,16,18,19,24]$.

Other memes consistently crop up in these next economies initiatives' aspirations. Neoliberalism acknowledges responsibility - but only on individual (and individual company) terms, because of the belief that there is no such thing as society. Next economies initiatives in contrast argue (using these types of memes) for connection, relationship, interdependence (among people and with nature), and community, essentially for shared responsibility for the whole system at whatever level is contextually appropriate. Some argue for localization as a way of reducing ecological impacts, while The Alternative UK has developed an insightful framing that argues for linkage between the cosmopolitan (global) and the local—or what, for short, is called cosmo-local (as a better alternative to the fraught term "glocal", which combines local and global) [52]. Further, in contrast to ignoring societal impacts, words like care, compassion, dignity for all, equity, fairness, and justice build a sense of responsibility or stewardship for communities, societies, and, indeed, the whole of life, which are common next economies' memes. While much work has been done on corporate social responsibility in the past, these ideas imply entirely different ways of doing business and approaches to stakeholders that are subjects of much needed research.

Underpinning many next economies articulations is a deeply and profoundly renewed, revitalized relationship between humans and nature—one that draws from the wisdom of Indigenous thinkers [53]. In much Western thought and deeply embedded in neoliberalism is a distinct separation of humankind from nature, with the (possibly misinterpreted) biblical idea that "man" should have "dominion over" nature. Rather than this separation, which is very much aligned with a similar separation of mind from body in Western tradition, many next economies initiatives take a perspective far more similar to Indigenous thinking, which recognizes our human integral relationship with and interdependence with nature $[23,53]$. This major mindset shift bubbled up in many places and settings around the 
planet, particularly as people recognized how nature began to recover from human impacts during the shutdown of the pandemic. Terms like reciprocity, circularity, regenerativity, resilience, and cyclicality are often used to express this renewed, more harmonious and better-balanced relationship with nature. It is distinctly opposed to the attitude in current economic (and cultural) thinking that basically argues that because "man" has dominion over nature, her resources are simply there for human exploitation.

Another shift in next economies thinking is away from cutthroat competition towards a more collaborative stance that recognizes, as do biologists and evolutionary theorists, that symbiosis and cooperation are essential to what gives life to human and ecological systems [42,43]. In the context of a collaborative stance, there is also recognition of the need for equal and participative inclusion of voices that have been under-represented, marginalized, or colonized in the past, including youth, Indigenous peoples, poor people, and future generations.

\section{Future Research: Transformation-What Still Needs Change}

Both businesses and the b-schools that educate their leaders and managers are implicated in the need to manage through, during, and in the manifold crises in the world today. Collectively, they-we-need to shape, teach, and implement ideas that emphasize wellbeing for all, not for the lucky few, and where "all" also includes non-human beings. Perhaps more importantly, there is an emerging global recognition by citizens, activists, progressive thought leaders, academics, and others of this need to re-vision and implement a major transformation of the thinking that informs both b-schools and businesses so they can shift to better meet the demands of the 21st century. This transformation is far from the return to business as usual that most business leaders and policy makers seem to be imagining. Rather, as discussed, it means significant transformation in economic thinking, business purposes and practices, the performance metrics that guide those purposes and practices, and in how business is understood as an institution. It means new paradigms and mindsets.

Some of this transformation thinking has been translated through the currently popular idea, the meme, of "build back better" in the wake of the Covid-19 pandemic. This idea can be viewed as a way of pushing institutions of all sorts to better deal with sustainability and climate change emergency, as well as other crises, particularly by changing economics and business systems. Institutions as different as the United Nations, the We Mean Business Coalition, the Wellbeing Economy Alliance (WEAll), and Fast Company magazine, among others, used the "build back better" language, while the SDG Transformations Forum was using the term "bounce beyond" to indicate a desire to move transformatively away from the prior system.

These phrases signify growing concern with business as usual and recognition of a need for businesses in particular to transform towards what Ehrenfeld and Hoffman called actual sustainability (as opposed to simply less unsustainability) in the wake of the pandemic [44]. Underlying this and related phrases or memes is a desire on the part of many observers to see the entire system work in a different way than it has been doing. Even the World Economic Forum made the link between the destruction of the natural environment, the emergence of the pandemic, and the significant economic consequences that ensued ("COVID-19 is a stark reminder that our assault on the natural world has consequences.").

Seeds of this transformation have already been planted in initiatives like The Investment Integration Project, which is attempting to update finance's modern portfolio to include systemic risks. Integrated reporting provides pathways for accounting for not just financial implications of business but also their environmental, social, and governance (ESG) practices. Ideas about regenerative capitalism offered by John Fullerton through the Capital Institute are helping people in the finance community start to reimagine economics and finance through an ecological lens. On the management education side, the Principles for Responsible Management Education argues for management education to work for an "inclusive and sustainable global economy", and the AACSB accrediting body argues for a "collective vision" that will and should transform business and business education. 


\section{Conclusions}

A broadened set of principles on which economies rest is sorely needed to cope with the manifold crises posed by not only the pandemic but also climate change, biodiversity loss, growing inequality, and numerous other civilization-threatening emergencies [54]. Various initiatives have begun building new language and frameworks that are useful. Two are highlighted here to indicate not only that changing paradigms and memes is possible but that it is beginning to happen. WEAll has numerous next economy allies (more than 150 at this writing), and the values that it associates with a "wellbeing economy" may be relevant as a guide to how both businesses and b-schools can begin to shift. In their brochure WEAll states, “WEAll need ...

1. Dignity: Everyone has enough to live in comfort, safety and happiness

2. Nature: A restored and safe natural world for all life

3. Connection: A sense of belonging and institutions that serve the common good

4. Fairness: Justice in all its dimensions at the heart of economic systems, and the gap between the richest and poorest greatly reduced

5. Participation: Citizens are actively engaged in their communities and locally rooted economies (WEAll brochure) [55]

Another approach to 21st century economies that has gained a lot of notice over the past several years-and provides a clear alternative to neoliberalism-is Raworth's "doughnut economics", an economics designed to the needs of all within planetary means [21]. The "doughnut" draws from the Stockholm Resilience Institute's work on planetary boundaries, which argues that there are nine geophysical planetary boundaries that cannot be transgressed without great civilizational risk (though four have already been exceeded) [56]. Raworth combines the planetary boundaries image on the outside boundary of her doughnut, with twelve necessary social foundations on the inside boundary that create social boundaries. She argues that meeting all of these needs can provide a foundation of wellbeing for all: sufficient food, health, education, income and work, peace and justice, political voice, social equity, gender equality, housing, networks, energy, and water [21]. At this writing, the entire city of Amsterdam has agreed to transform itself around the principles of Raworth's model.

The specific framework or model used matters less than achieving some degree of agreement on the need for and content of a new economics paradigm, or perhaps more importantly, new resonant and inspirational memes, so that economies can be redesigned, as corporations must also be [57]. For both businesses, whose purposes, strategies, and operating practices will change dramatically towards meeting real needs by creating collective value, and for $b$-schools, transformation is needed to ensure that the boundary conditions that create wellbeing, flourishing, regenerative capacity, or collective value, by whatever name it is given, are met. Given that the Intergovernmental Panel on Climate Change (IPCC) claims that humanity has until 2030 to make significant changes in its trajectory, no time can be wasted [58].

Funding: No external funding was used to produce this paper.

Conflicts of Interest: The author declares no conflicts of interest.

\section{References}

1. Fotaki, M.; Prasad, A. Questioning neoliberal capitalism and economic inequality in business schools. Acad. Manag. Learn. Educ. 2015, 14, 556-575. [CrossRef]

2. Díaz, S.; Settele, J.; Brondízio, E.; Ngo, H.; Guèze, M.; Agard, J.; Arneth, A.; Balvanera, P.; Brauman, K.; Butchart, S.; et al. Summary for Policymakers of the Global Assessment Report on Biodiversity and Ecosystem Services of the Intergovernmental Science-Policy Platform on Biodiversity and Ecosystem Services. Intergovernmental Science-Policy Platform on Biodiversity and Ecosystem Servicesm. 2020. Available online: https://ipbes.net/sites/default/files/2020-02/ipbes_global_assessment_report_summary_for_ policymakers_en.pdf (accessed on 24 July 2020). 
3. WWF. 2018 Living Planet Report: Aiming Higher; WWF: Gland, Switzerland, 2018.

4. Our future on earth. FutureEarth, 6 June 2010. Available online: https://futureearth.org/publications/our-fut ure-on-earth/ (accessed on 24 July 2020).

5. Neal, M. Learning from Poverty: Why business schools should address poverty, and how they can go about it. Acad. Manag. Learn. Educ. 2017, 16, 54-69. [CrossRef]

6. Pless, N.; Maak, T. Responsible leadership: Pathways to the future. J. Bus. Ethics 2011, 98, 3-13. [CrossRef]

7. Maak, T.; Pless, N. Responsible leadership in a stakeholder society-A relational perspective. J. Bus. Ethics 2006, 66, 99-115. [CrossRef]

8. Lewin, K. The research center for group dynamics at massachusetts institute of technology. Sociometry 1945, 8, 126-136. [CrossRef]

9. Snelson-Powell, A.; Grosvold, J.; Millington, A.; Powell, A. Business school legitimacy and the challenge of sustainability: A fuzzy set analysis of institutional decoupling. Acad. Manag. Learn. Educ. 2016, 15, 703-723. [CrossRef]

10. Lovins, H. Needed: A better story. Humanist. Manag. J. 2016, 1, 75-90. [CrossRef]

11. Lovins, L.H.; Wallis, S.; Wijkman, A.; Fullerton, J. A Finer Future: Creating an Economy in Service to Life; New Society Publishers: Gabriola, BC, Canada, 2018.

12. Waddock, S. Achieving sustainability requires systemic business transformation. Glob. Sustain. 2020, 3, 1-12. [CrossRef]

13. Wright, C.; Nyberg, D. An inconvenient truth: How organizations translate climate change into business as usual. Acad. Manag. J. 2017, 60, 1633-1661. [CrossRef]

14. Cheit, E.F. Business schools and their critics. Calif. Manag. Rev. 1985, 27, 43-62. [CrossRef]

15. Ghoshal, S. Bad management theories are destroying good management practices. Acad. Manag. Learn. Educ. 2005, 4, 75-91. [CrossRef]

16. Datar, S.M.; Garvin, D.A.; Cullen, P.G. Rethinking the MBA: Business Education at a Crossroads; Harvard Business Press: Cambridge, MA, USA, 2010.

17. Leavitt, H.J. Educating our MBAs: On teaching what we haven't taught. Calif. Manag. Rev. 1989, 31, 38-50. [CrossRef]

18. Pfeffer, J. Why do bad management theories persist? A comment on ghoshal. Acad. Manag. Learn. Educ. 2005, 4, 96-100. [CrossRef]

19. Tourish, D. The triumph of nonsense in management studies. Acad. Manag. Learn. Educ. 2019, 19, 99-109. [CrossRef]

20. Bunch, K.J. State of undergraduate business education: A perfect storm of climate change? Acad. Manag. Learn. Educ. 2020, 19, 81-98. [CrossRef]

21. Raworth, K. Doughnut Economics: Seven Ways to Think Like a 21st-Century Economist; Chelsea Green Publishing: White River Junction, VT, USA, 2017.

22. Korten, D. Ecological civilization and the new enlightenment. Tikkun 2017, 32, 17-24. [CrossRef]

23. Korten, D.C. Change the Story, Change the Future: A Living Economy for a Living Earth; Berrett-Koehler Publishers: San Francisco, CA, USA, 2015.

24. Aragon-Correa, J.A.; Marcus, A.A.; Rivera, J.E.; Kenworthy, A.L. Sustainability management teaching resources and the challenge of balancing planet, people, and profits. Acad. Manag. Learn. Educ. 2017, 16, 469-483. [CrossRef]

25. Waddell, S. Change for the Audacious: A Doer's Guide to Large Systems Change for Flourishing Futures; Networking Action: Boston, MA, USA, 2016.

26. Currie, G.; Davies, J.; Ferlie, E. A call for university-based business schools to "lower their walls:" Collaborating with other academic departments in pursuit of social value. Acad. Manag. Learn. Educ. 2016, 15, 742-755.

27. Sneader, K.; Sternfels, B. From Surviving to Thriving: Business after Coronavirus. Available online: https://www.mckinsey.com/featured-insights/future-of-work/from-surviving-to-thriving-reimagi ning-the-post-covid-19-return (accessed on 24 July 2020).

28. Byrne, J.A. What Business Schools Will Look Like after the Pandemic. 2020. Available online: https: //poetsandquants.com/2020/04/22/what-business-schools-will-look-like-after-the-pandemic/ (accessed on 24 July 2020).

29. Freeman, R.E. The new story of business: Towards a more responsible capitalism. Bus. Soc. Rev. 2017, 122, 449-465. 
30. Riedy, C. Storying the Future: Storytelling practice in transformative systems. In Storytelling for Sustainability in Higher Education; Molthan-Hill, P., Luna, H., Wall, T., Puntha, H., Baden, D., Eds.; Routledge: Abington, UK, 2020.

31. Dow, J. Universal aspects of symbolic healing: A theoretical synthesis. Am. Anthr. 1986, 88, 56-69. [CrossRef]

32. Monbiot, G. Neoliberalism-The Ideology at the Root of all of Our Problems. 2020. Available online: https: //www.theguardian.com/books/2016/apr/15/neoliberalism-ideology-problem-george-monbiot (accessed on 24 July 2020).

33. Meadows, D. Leverage Points: Places to Intervene in a System. 17 June 2020. Donella Meadows Institute. Available online: http://donellameadows.org/archives/leverage-points-places-to-intervene-in-a-system/ (accessed on 24 July 2020).

34. Dawkins, R. The Selfish Gene; Oxford University Press: Oxford, UK, 1976.

35. Blackmore, S. The Meme Machine; Oxford Paperbacks: Oxford, UK, 2000.

36. Waddock, S. Foundational memes for a new narrative about the role of business in society. Humanist. Manag. J. 2016, 1, 91-105. [CrossRef]

37. Giacalone, R.A.; Wargo, D.T. The roots of the global financial crisis are in our business schools. J. Bus. Ethics Educ. 2009, 6, 147-168.

38. Handy, C. What's a business for? Harv. Bus. Rev. 2002, 80, 48-55.

39. Waddock, S. Transforming Towards Life: How Everyone Can Help Business, Government, and Civil Society Build a Better World for All; Business Expert Press: New York, NY, USA, 2020.

40. Friedman, M. The social responsibility of business is to increase its profits. The New York Times Magazine, 13 September 1970; pp. 173-178.

41. Pirson, M. Humanistic Management: Protecting Dignity and Promoting Well-Being; Cambridge University Press: Cambridge, UK, 2017.

42. De Waal, F.B. Good Natured; Harvard University Press: Cambridge, MA, USA, 1996.

43. Atkins, P.W.; Wilson, D.S.; Hayes, S.C. Prosocial: Using Evolutionary Science to Build Productive, Equitable, and Collaborative Groups; New Harbinger Publications: Oakland, CA, USA, 2019.

44. Ehrenfeld, J.; Hoffman, A.J. Flourishing: A Frank Conversation about Sustainability; Stanford Business Books: Palo Alto, CA, USA, 2013.

45. Eisler, R. The Real Wealth of Nations: Creating a Caring Economics; Berrett-Koehler Publishers: San Francisco, CA, USA, 2008.

46. Davis, G.F. The Vanishing American: Navigating the Hazards of a New Economy; Berrett-Koehler Publishers: San Francisco, CA, USA, 2016.

47. Costanza, R.; Hart, M.; Posner, S.; Talberth, J. Beyond GDP: The need for new measures of progress. Pardee Pap. 2009, 4, 1-46.

48. Donaldson, T.; Walsh, J.P. Toward a theory of business. Res. Organ. Behav. 2015, 35, 181-207. [CrossRef]

49. Rimanoczy, I.; Laszlo, E. Big Bang Being: Developing the Sustainability Mindset; Routledge: Abington, UK, 2017.

50. Waddock, S. Leadership Ethics for a Troubled World: Responsibility for the Whole. Ethical Business Leadership in Troubling Times; Edward Elgar Publishing: Northampton, MA, USA, 2019.

51. Kelly, M.; White, A.L. Turning point. from corporate responsibility to corporate design: Rethinking the purpose of the corporation. J. Corp. Citizsh. 2009, 33, 23-27. [CrossRef]

52. Adnan, I. The Politics of Waking Up 1: Power and Possibility in the Fractal Age. Emerge, 21 September 2019. Available online: https://www.whatisemerging.com/opinions/the-politics-of-waking-up-power-and-possib ility-in-the-fractal-age (accessed on 24 July 2020).

53. Four Arrows. Point of Departure: Returning to Our More Authentic Worldview for Education and Survival; IAP: Charlotte, NC, USA, 2016.

54. Diamond, J.M. Collapse: How Societies Choose to Fail or Succeed; Viking: New York, NY, USA, 2005.

55. Wellbeing Economy Alliance Vision. 2020. Available online: https://wellbeingeconomy.org/wp-content/uplo ads/2020/01/WEAll-brochure_Jan20_S.pdf (accessed on 24 July 2020).

56. Rockström, J.; Steffen, W.; Noone, K.; Persson, Å.; Chapin, F.S.; Lambin, E.F.; Lenton, T.M.; Scheffer, M.; Folke, C.; Schellnhuber, H.J.; et al. A safe operating space for humanity. Nature 2009, 461, 472-475. [CrossRef]

57. White, A. Corporation 2020. 2013. Tellus Institute. Available online: https://www.corporation2020.org/ (accessed on 24 July 2020). 
58. Zhai, P.; Pörtner, H.O.; Roberts, D.; Skea, J.; Shukla, P.R.; Pirani, A.; Moufouma-Okia, W.; Péan, C.; Pidcock, R.; Connors, S. Global Warming of 1.5 OC: An IPCC Special Report on the Impacts of Global Warming of $1.5 \hat{A}^{\circ} \mathrm{C}$ Above Pre-Industrial Levels and Related Global Greenhouse Gas Emission Pathways, in the Context of Strengthening the Global Response to the Threat of Climate Change, Sustainable Development, and Efforts to Eradicate Poverty; World Meteorological Organization: Geneva, Switzerland, 2018. 